\title{
Concentrations of strontium, barium, cadmium, copper, zinc, manganese, chromium, antimony, selenium and lead in the equine liver and kidneys
}

\author{
Nadine Paßlack ${ }^{1 *}$, Barbara Mainzer ${ }^{1,2}$, Monika Lahrssen-Wiederholt ${ }^{2}$, Helmut Schafft $^{2}$, Richard Palavinskas ${ }^{2}$,
} Angele Breithaupt ${ }^{3}$, Konrad Neumann $^{4}$ and Jürgen Zentek ${ }^{1}$

\begin{abstract}
The concentrations of specific elements in the equine liver and kidneys are of practical relevance since horses are not only food-producing animals, but also partially serve as an indicator for the environmental pollution, as the basic feed includes plants like grass, grain and fruits. In this study, the concentrations of strontium (Sr), barium (Ba), cadmium (Cd), copper (Cu), zinc (Zn), manganese (Mn), chromium (Cr), antimony (Sb), selenium (Se) and lead (Pb) were measured in the liver, renal cortex and renal medulla of 21 horses (8 male; 13 female; aged between 5 months-28 years), using inductively coupled plasma mass spectrometry. Comparable Cu and Zn concentrations were detected in the liver and renal cortex, while approximately 50\% lower concentrations were measured in the renal medulla. The lowest $\mathrm{Sr}, \mathrm{Cd}$ and $\mathrm{Se}$, but the highest $\mathrm{Mn}, \mathrm{Sb}$ and $\mathrm{Pb}$ concentrations were measured in the liver. The Ba concentrations were comparable in the renal cortex and medulla, but lower in the liver of the horses. Gender-related differences were observed for $\mathrm{Cd}, \mathrm{Mn}$ and $\mathrm{Cr}$, with higher $\mathrm{Cd}$ concentrations in the liver, but lower $\mathrm{Mn}$ concentrations in the renal cortex and lower $\mathrm{Cr}$ concentrations in the renal medulla of female horses. Age-related differences were detected for most measured elements, however, the animal number per age-group was only low. In conclusion, the present study provides important reference data for the storage of $\mathrm{Sr}, \mathrm{Ba}, \mathrm{Cd}, \mathrm{Cu}$, $\mathrm{Zn}, \mathrm{Mn}, \mathrm{Cr}, \mathrm{Sb}$, Se and $\mathrm{Pb}$ in the liver and kidneys of horses, which are of practical relevance for an evaluation of the exposure of horses to these elements, either via feed or the environment.
\end{abstract}

Keywords: Horses; Elements; Liver and kidneys; Feed; Environment

\section{Introduction}

In many countries, horses are food-producing animals and the storage of specific elements in the equine muscles and organs can become relevant for human and animal nutrition. The statistical office of the European Union (Eurostat) indicates that 214526 equids, including mainly horses, but also asses, mules and hinnies, were slaughtered in the European Union in the year 2007, with the highest rate in Italy (46.6\%). In Germany, the per capita consumption of horse meat is low $(0.04 \mathrm{~kg})$, while other countries like Italy $(1 \mathrm{~kg})$, Luxembourg $(0.68 \mathrm{~kg})$ or France $(0.35 \mathrm{~kg})$ show a higher per capita consumption (Eurostat). Besides the relevance of horses for the food

\footnotetext{
* Correspondence: nadine.passlack@fu-berlin.de

${ }^{1}$ Institute of Animal Nutrition, Department of Veterinary Medicine, Freie

Universität Berlin, Königin-Luise-Str. 49, Berlin 14195, Germany

Full list of author information is available at the end of the article
}

chain, these animals can partly be important as indicator for environmental pollution, as plants, the equine basic food resource, incorporate elements depending on the concentrations in the soil or air. For instance, horses are postulated to be an indicator for the cadmium $(\mathrm{Cd})$ pollution of the environment (Elinder 1981). In this context, also other elements are of interest: the radioactive strontium $\left({ }^{90} \mathrm{Sr}\right)$ is an important contaminant in soil, since it was released during overhead nuclear weapon tests in the 1950s and 1960s. The transition to plants and consecutively to food-producing animals and humans is intensively discussed since the 1960s. Beside Cd and Sr, antimony $(\mathrm{Sb})$ is also interesting for an evaluation of the environmental exposition of horses. It has been reported (Daunderer 1998) that the air in Europe contains $8 \mathrm{ng} \mathrm{Sb} / \mathrm{m}^{3}$ and the sea water $0.2 \mu \mathrm{g} / \mathrm{l}$, while stream water contains $0.1-1 \mu \mathrm{g} / \mathrm{l}$, and markedly higher concentrations 
(>1000 $\mu \mathrm{g} / \mathrm{kg}$ dry matter) can be found in spruce needles, leaves of fruit-bearing trees and grass (Streit 1994). Moreover, the alkaline earth metal barium $(\mathrm{Ba})$ is of interest. Ba shows a high reactivity and therefore exists in nature only in form of Ba compounds. Since only few information is available on the relevance of $\mathrm{Ba}$ for horses or other animals, the present study may help to generate new knowledge on its storage in the equine organs. Finally, lead (Pb) is an important environmental contaminant that can be ingested by water, soil and food (Brown and Margolis 2012). Since $\mathrm{Pb}$ accumulates in the organism, noxious effects can appear as a result of a high exposition (Ciobanu et al. 2012).

Beside the equine exposition to environmental contaminants, such as $\mathrm{Cd}, \mathrm{Sr}, \mathrm{Sb}, \mathrm{Ba}$ and $\mathrm{Pb}$, the intake of essential trace elements is of practical relevance. In particular, zinc $(\mathrm{Zn})$, copper $(\mathrm{Cu})$, chromium $(\mathrm{Cr})$, manganese $(\mathrm{Mn})$ and selenium (Se) should be considered. Since these elements can not only be provided by basic feed like hay or grain, but also by feed supplements, high individual variations in the element concentrations of equine organs can be assumed. However, considering that only few data on the $\mathrm{Zn}, \mathrm{Cu}, \mathrm{Cr}, \mathrm{Mn}$ and Se concentrations in horses are available and that the corresponding studies were often performed several decades ago, further studies are needed to provide actual reference data. Moreover, since horses often reach a high age, a differentiation between several age-groups is reasonable, but also a differentiation between male and female horses, as a sexual dimorphism may occur for the accumulation of the elements in the equine organism.

The present study aimed at measuring the concentrations of $\mathrm{Sr}, \mathrm{Ba}, \mathrm{Cd}, \mathrm{Cu}, \mathrm{Zn}, \mathrm{Mn}, \mathrm{Cr}, \mathrm{Sb}, \mathrm{Se}$ and $\mathrm{Pb}$ in the liver, renal cortex and renal medulla of horses of different age and sex, providing actual data on the accumulation of these elements in typical storage organs. Therefore, inductively coupled plasma mass spectrometry (ICP-MS) was used. Since horses are also food-producing animals, the amounts of the elements in the liver and kidneys are of practical relevance, as these organs are edible animal by-products, used especially for animal nutrition, but also for humans.

\section{Material and methods}

\section{Tissue samples and analysis}

Liver and kidney samples of 10 euthanized horses were collected during routine post-mortem examinations in the Institute of Veterinary Pathology, Department of Veterinary Medicine, Freie Universität Berlin. Moreover, samples of 11 horses were collected in a local slaughterhouse (Roßschlächtermeister Frank Plaumann, Prenzlau, Germany). The euthanasia and the slaughtering were carried out according to the German Tierschutzgesetz (animal welfare act), while details on the drugs for the euthanasia are unspecified. The euthanasia and slaughtering were only based on medical purpose and were not performed to collect tissues for the present study or for the reason of other research. None of the authors participated in the euthanasia or slaughtering of the animals, but only obtained the samples in the Institute of Veterinary Pathology or directly in the slaughterhouse. The pathomorphological findings of the horses are summarized in Additional file 1: Table S1. The horses (8 male, $13 \mathrm{fe}-$ male) were aged between 5 months- 28 years.

Before further analysis, all tissues were stored in polyethylene bags and frosted at $-18^{\circ} \mathrm{C}$. For the pathomorphological investigation, representative tissue samples were fixed in $4 \%$ neutral-buffered formaldehyde and embedded in paraffin. The samples were sectioned at $4 \mu \mathrm{m}$, mounted on glass slides and stained with haematoxylin and eosin (H\&E).

\section{Preparation of the samples}

The tissue samples were defrosted at room temperature, and $0.5 \mathrm{~g}$ of each sample was mixed with $5 \mathrm{ml}$ concentrated nitric acid (65\%) in a quartz vessel. This vessel was put into a Teflon ${ }^{\circledR}$ capsule, which was prepared with $5 \mathrm{ml}$ bidistilled water and $2 \mathrm{ml}$ hydrogen peroxide. Afterwards, a wet-chemical digestion was performed in a microwave (MLS GmbH, Leutkirch, Germany), where the Teflon ${ }^{\bullet}$ capsule was placed in a pressure vessel. The acid digestion lasted for $1 \mathrm{~h}$, and maximum temperatures of $200^{\circ} \mathrm{C}$ were reached. After cooling, the samples were pipetted into graduated flasks that were provided with bidistilled water. The graduated flasks were filled up with bidistilled water to a total volume of $50 \mathrm{ml}$ before the further measurement of the elements.

\section{Measurement of the elements}

The concentrations of $\mathrm{Sr}, \mathrm{Ba}, \mathrm{Cd}, \mathrm{Cu}, \mathrm{Zn}, \mathrm{Mn}, \mathrm{Cr}, \mathrm{Sb}, \mathrm{Se}$ and $\mathrm{Pb}$ were measured using ICP-MS (model ELEMENT 1, Finnigan MAT, Bremen, Germany).

For quality assurance, the certified NBS SRM biological standard 1577 (bovine liver) (Spex Industries $\mathrm{GmbH}$, Grasbrunn, Germany) was digested in the same way as all the samples and measured with the ICP-MS using the same method as for all samples. The results of the analyzed Certified Reference Material are presented in Table 1. For quality control (QC), the solution of a digested horse liver was used. The sample amount was $20 \mathrm{~g}$ digested in 20 parts and diluted in 11 water containing $6 \%$ nitric acid. The loop for the measurements was: blank, sample, sample, blank, QC-solution, sample, sample etc. During the entire series, the variation of the elements in the QC-solution was in between $10 \%$. The detection limit (Table 2) was estimated from the mean of the blank, the standard deviation of the blank and some confidence factor. 
Table 1 Results (expressed in $\mathrm{mg} / \mathrm{kg}$ ) of the analyzed Certified Reference Material NBS SRM biological standard 1577 (bovine liver)

\begin{tabular}{lcc}
\hline & Certified value & Found \\
\hline Sr & 140 (not certified) & $135 \pm 9$ \\
$\mathrm{Ba}$ & 0.94 (not certified) & $0.89 \pm 0.06$ \\
$\mathrm{Cd}$ & $0.44 \pm 0.06$ & $0.48 \pm 0.06$ \\
$\mathrm{Cu}$ & $158 \pm 7$ & $156 \pm 8$ \\
$\mathrm{Zn}$ & $123 \pm 8$ & $120 \pm 9$ \\
$\mathrm{Mn}$ & $9.9 \pm 0.8$ & $9.5 \pm 0.8$ \\
$\mathrm{Cr}$ & 0.15 (not certified) & $0.19 \pm 0.06$ \\
$\mathrm{Sb}$ & 0.0003 (not certified) & Not detected \\
$\mathrm{Se}$ & $0.71 \pm 0.07$ & $0.69 \pm 0.07$ \\
$\mathrm{~Pb}$ & $0.135 \pm 0.015$ & $0.132 \pm 0.012$ \\
\hline
\end{tabular}

\section{Statistical analysis of the data}

The data were analyzed using SPSS 15 (Chicago, USA). For the comparisons of the element concentrations in the liver, renal cortex and renal medulla of the horses, Friedman tests for dependent samples were performed. In case of a significant Friedman test, Wilcoxon signed rank tests were used to compare the element concentrations among the tissues (Table 3). For the evaluation of gender-related (Table 4) and age-related (Table 5) group differences $(P<0.05)$, the non-parametric Mann-Whitney$\mathrm{U}$-Test was performed. For the detection of the age-related differences, the horses were divided into different age groups. The dependence of the element concentrations in the liver, renal cortex and renal medulla on the sex and age (not classified) of the horses was examined (Table 6) using linear models with factor sex and covariate age (years). The level of significance was $\alpha=0.05$. Since the data were not normally distributed, the data are presented as median (minimum-maximum) in all tables.

Table 2 Limit of detection $(\mu \mathrm{g} / \mathrm{kg})$ and limit of quantification $(\mu \mathrm{g} / \mathrm{kg})$ in the present study

\begin{tabular}{lcc}
\hline & Limit of detection & Limit of quantification \\
\hline $\mathrm{Sr}$ & 0.007 & 0.021 \\
$\mathrm{Ba}$ & 0.007 & 0.021 \\
$\mathrm{Cd}$ & 0.056 & 0.168 \\
$\mathrm{Cu}$ & 0.053 & 0.159 \\
$\mathrm{Zn}$ & 0.041 & 0.123 \\
$\mathrm{Mn}$ & 0.077 & 0.231 \\
$\mathrm{Cr}$ & 0.056 & 0.168 \\
$\mathrm{Sb}$ & 0.006 & 0.018 \\
$\mathrm{Se}$ & 0.500 & 1.500 \\
$\mathrm{~Pb}$ & 0.006 & 0.018 \\
\hline
\end{tabular}

\section{Results}

Total concentrations of $\mathrm{Sr}, \mathrm{Ba}, \mathrm{Cd}, \mathrm{Cu}, \mathrm{Zn}, \mathrm{Mn}, \mathrm{Cr}$, Sb, Se and $\mathrm{Pb}$ in the liver, cortex of the kidney and renal medulla The detection of the elements in the liver and kidney of the horses revealed large individual differences (Table 3). The Sr concentrations were the lowest in the liver (73.5 $(23.5-283) \mu \mathrm{g} / \mathrm{kg})$, followed by the renal cortex $(170$ $(59.3-466) \mu \mathrm{g} / \mathrm{kg}$ ) and the renal medulla (248 (40.7-1017) $\mu \mathrm{g} / \mathrm{kg})(P<0.05)$. In contrast, the highest concentrations of $\mathrm{Mn}$ and $\mathrm{Sb}$ were detected in the liver compared to the cortex or medulla of the kidneys $(P<0.05) . \mathrm{Cu}$ and $\mathrm{Zn}$ were the lowest in the renal medulla when compared to the liver and the renal cortex $(P<0.05)$. The measured hepatic $\mathrm{Ba}$ concentrations amounted to 230 (107-427) $\mu \mathrm{g} / \mathrm{kg}$, while medians between $340-355 \mu \mathrm{g} / \mathrm{kg}$ were measured in the kidney $(P<0.05)$. The highest $\mathrm{Cd}$ and $\mathrm{Se}$ concentrations were detected in the renal cortex of the horses, followed by the renal medulla and the liver $(P<$ 0.05). Markedly higher $\mathrm{Pb}$ concentrations were detected in the liver $(82.3(0.00-301) \mu \mathrm{g} / \mathrm{kg})$ of the horses when compared to the renal cortex $(34.0(0.00-118) \mu \mathrm{g} / \mathrm{kg})$ and the renal medulla $(18.2(0.00-103) \mu \mathrm{g} / \mathrm{kg})(P<0.05)$.

\section{Gender-specific differences}

The sex of the horses had only minor impact on the concentrations of the measured elements in the liver and kidney of the horses (Table 4). Higher concentrations of $\mathrm{Cd}$ were found in the liver of female horses (1074 (551-3700) $\mu \mathrm{g} / \mathrm{kg})$ compared to male horses (475 (67.6-3669) $\mu \mathrm{g} / \mathrm{kg} ; P<0.05)$. Moreover, male horses showed higher concentrations of $\mathrm{Mn}$ in the renal cortex (1261 (564-1479) $\mu \mathrm{g} / \mathrm{kg}$ ) compared to female horses (805 $(344-1268) \mu \mathrm{g} / \mathrm{kg} ; P<0.05)$. The linear model also detected a gender-dependent difference $(P=0.015)$ for the storage of $\mathrm{Cr}$ in the renal medulla, where lower concentrations were found in female horses $(82.7(27.6-175) \mu \mathrm{g} / \mathrm{kg})$ compared to male horses (106 (84.4-348) $\mu \mathrm{g} / \mathrm{kg})$.

\section{Age-related differences}

The age-related differences in the element concentrations in the liver and kidney of the horses are presented in Table 5. In particular, the $\mathrm{Cd}$ concentrations varied depending on the age of the animals, with lower concentrations in the liver of young horses ( $0-4$ years) compared to older horses (9-28 years). Similar results were observed in the renal cortex, where markedly lower $\mathrm{Cd}$ concentrations (3065 (315-8713) $\mu \mathrm{g} / \mathrm{kg}$ ) were measured in horses up to 1 year compared to horses between $16-28$ years (24027 $(3048-36562) \mu \mathrm{g} / \mathrm{kg})(P<0.05)$. The Cd concentrations were also lower in the renal medulla of younger horses than in older horses, demonstrating differences $(P<0.05)$ when comparing the age group $0-1$ year with the group 16-28 years and also horses between $2-8$ years with 9-13 years old horses. 
Table 3 Concentrations ( $\mu \mathrm{g} / \mathrm{kg}$ ) of strontium (Sr), barium (Ba), cadmium (Cd), copper (Cu), zinc (Zn), manganese (Mn), chromium $(\mathrm{Cr})$, antimony $(\mathrm{Sb})$, selenium $(\mathrm{Se})$ and lead $(\mathrm{Pb})$ in the liver and kidneys of horses $(n=21)$

\begin{tabular}{lllllll}
\hline & \multicolumn{2}{c}{ Liver } & \multicolumn{2}{c}{ Cortex of the kidney } & \multicolumn{2}{c}{ Renal medulla } \\
\hline Sr & 73.5 & $(23.5-283)^{\mathrm{a}}$ & 170 & $(59.3-466)^{\mathrm{b}}$ & 248 & $(40.7-1017)^{\mathrm{c}}$ \\
$\mathrm{Ba}$ & 230 & $(107-427)^{\mathrm{a}}$ & 340 & $(154-570)^{\mathrm{b}}$ & 355 & $(179-982)^{\mathrm{b}}$ \\
$\mathbf{C d}$ & 798 & $(67.6-3700)^{\mathrm{a}}$ & 8713 & $(315-42819)^{\mathrm{b}}$ & 4647 & $(77.5-35091)^{\mathrm{c}}$ \\
$\mathbf{C u}$ & 4238 & $(2151-14609)^{\mathrm{a}}$ & 4448 & $(2488-11393)^{\mathrm{a}}$ & 1853 & $(1100-6511)^{\mathrm{b}}$ \\
$\mathbf{Z n}$ & 21387 & $(8849-96681)^{\mathrm{a}}$ & 21956 & $(12323-47110)^{\mathrm{a}}$ & 12895 & $(8573-24653)^{\mathrm{b}}$ \\
$\mathbf{M n}$ & 1186 & $(515-3258)^{\mathrm{a}}$ & 875 & $(344-1479)^{\mathrm{b}}$ & 412 & $(242-1292)^{\mathrm{c}}$ \\
$\mathbf{C r}$ & 116 & $(22.0-427)$ & 84.7 & $(16.3-514)$ & 91.5 & $(27.6-348)$ \\
$\mathbf{S b}$ & 14.8 & $(0.00-23.8)^{\mathrm{a}}$ & 10.8 & $(0.00-13.5)^{\mathrm{b}}$ & 10.8 & $(0.00-12.0)^{c}$ \\
$\mathbf{S e}$ & 131 & $(69.6-336)^{\mathrm{a}}$ & 739 & $(356-1599)^{\mathrm{b}}$ & 255 & $(87.5-647)^{\mathrm{c}}$ \\
$\mathbf{P b}$ & 82.3 & $(0.00-301)^{\mathrm{a}}$ & 34.0 & $(0.00-118)^{\mathrm{b}}$ & 18.2 & $(0.00-103)^{\mathrm{c}}$ \\
\hline
\end{tabular}

Differences $(P<0.05)$ within a row are marked with different superscript letters.

The $\mathrm{Cu}$ concentrations in the liver were the highest in horses up to 1 year (6057 (5609-14609) $\mu \mathrm{g} / \mathrm{kg})$, but lower $(P<0.05)$ in horses between $5-8(3172(2151-4613) \mu \mathrm{g} / \mathrm{kg})$ and 16-28 years $(4281(2403-5445) \mu \mathrm{g} / \mathrm{kg})$. In the renal medulla, the $\mathrm{Cu}$ concentrations were higher in horses between 9-13 years (2182 (1542-6511) $\mu \mathrm{g} / \mathrm{kg}$ ) compared to horses between 5-8 years (1295 (1100-1842) $\mu \mathrm{g} / \mathrm{kg})(P<0.05)$. Similar results were observed for $\mathrm{Zn}$, where the concentrations in the renal medulla were $60 \%$ higher in horses between 9-13 years compared to horses between $5-8$ years $(P<0.05)$.

The hepatic $\mathrm{Mn}$ and $\mathrm{Cr}$ concentrations were higher $(P<0.05)$ in very young horses $(0-1$ year $)$ when compared to older horses (9-13 years), and for Mn additionally when compared to middle-aged horses (5-8 years).

Horses between 5-8 years showed lower Se concentrations compared to horses between $16-28$ years (liver) or compared to horses between $0-1$ years and 9-28 years (renal medulla) $(P<0.05)$.

When the age of the horses was not classified (Table 6), a dependence for the storage of Se (liver) and $\mathrm{Cd}$ (renal cortex) on the age of the horses was detected $(P<0.05)$.

\section{Discussion}

This study provides new data on the storage of $\mathrm{Sr}, \mathrm{Ba}$, $\mathrm{Cd}, \mathrm{Cu}, \mathrm{Zn}, \mathrm{Mn}, \mathrm{Cr}, \mathrm{Sb}, \mathrm{Se}$ and $\mathrm{Pb}$ in the liver and kidneys of horses, considering the different age and the sex of the animals. As only few literature is available, the present data can be considered as important reference data, but also give some indication of the exposure of horses to specific elements in the environment or feed.

Although the background of the horses is not completely known, it can be assumed that the animals came from different areas of Germany. Since no fattening farms

Table 4 Concentrations ( $\mu \mathrm{g} / \mathrm{kg}$ ) of strontium ( $\mathrm{Sr})$, barium (Ba), cadmium (Cd), copper (Cu), zinc (Zn), manganese (Mn), chromium $(\mathrm{Cr})$, antimony $(\mathrm{Sb})$, selenium $(\mathrm{Se})$ and lead $(\mathrm{Pb})$ in the liver and kidneys of horses, depending on the sex of the animals $(\stackrel{1}{ }: \mathbf{n}=\mathbf{8} ;$

\begin{tabular}{|c|c|c|c|c|c|c|c|c|c|c|c|c|}
\hline & \multicolumn{4}{|c|}{ Liver } & \multicolumn{4}{|c|}{ Cortex of the kidney } & \multicolumn{4}{|c|}{ Renal medulla } \\
\hline & & $\hat{0}$ & & p & & $\hat{0}$ & & q & & $\hat{0}$ & & q \\
\hline Sr & 80.3 & $(26.3-135)$ & 67.7 & $(23.5-283)$ & 185 & $(59.3-251)$ & 168 & $(62.8-466)$ & 228 & $(87.6-360)$ & 295 & $(40.7-1017)$ \\
\hline $\mathrm{Ba}$ & 233 & $(214-271)$ & 230 & $(107-427)$ & 397 & $(240-570)$ & 323 & $(154-508)$ & 366 & $(221-564)$ & 355 & $(179-982)$ \\
\hline $\mathrm{Cd}$ & 475 & $(67.6-3669)^{\mathrm{a}}$ & 1074 & $(551-3700)^{b}$ & 7522 & $(315-42819)$ & 13967 & $(3048-36562)$ & 1776 & $(77.5-17500)$ & 5099 & $(489-35091)$ \\
\hline $\mathrm{Cu}$ & 5181 & $(2871-14609)$ & 4236 & $(2151-7966)$ & 4806 & (3009-10732) & 4448 & $(2488-11393)$ & 1960 & $(1131-5331)$ & 1842 & $(1100-6511)$ \\
\hline Zn & 22063 & (8849-96681) & 21387 & (12579-45690) & 22779 & $(13645-47110)$ & 21956 & (12323-44963) & 11624 & (9054-24653) & 12990 & (8573-21854) \\
\hline Mn & 2345 & $(515-3258)$ & 992 & $(544-2588)$ & 1261 & $(564-1479)^{a}$ & 805 & $(344-1268)^{b}$ & 540 & $(248-1292)$ & 372 & $(242-744)$ \\
\hline $\mathrm{Cr}$ & 119 & $(52.3-427)$ & 76.6 & $(22.0-178)$ & 100 & $(16.3-188)$ & 44.8 & $(17.0-514)$ & 106 & $(84.4-348)$ & 82.7 & $(27.6-175)$ \\
\hline $\mathrm{Sb}$ & 15.3 & $(0.00-21.6)$ & 0.35 & $(0.00-23.8)$ & 11.7 & $(0.00-12.5)$ & 0.00 & $(0.00-13.5)$ & 11.0 & $(0.00-11.6)$ & 0.00 & $(0.00-12.0)$ \\
\hline $\mathrm{Se}$ & 130 & $(69.6-319)$ & 151 & $(71.0-336)$ & 771 & $(462-1197)$ & 683 & (356-1599) & 264 & $(150-647)$ & 185 & $(87.5-522)$ \\
\hline $\mathrm{Pb}$ & 70.6 & $(25.9-158)$ & 90.7 & $(0.00-301)$ & 37.2 & $(0.00-114)$ & 32.6 & $(0.00-118)$ & 23.2 & $(0.00-40.5)$ & 16.1 & $(0.00-103)$ \\
\hline
\end{tabular}


Table 5 Concentrations ( $\mu \mathrm{g} / \mathrm{kg}$ ) of strontium $(\mathrm{Sr})$, barium (Ba), cadmium (Cd), copper $(\mathrm{Cu})$, zinc $(\mathrm{Zn})$, manganese (Mn), chromium $(\mathrm{Cr})$, antimony $(\mathrm{Sb})$, selenium $(\mathrm{Se})$ and lead $(\mathrm{Pb})$ in the liver and kidneys of horses, depending on the age of the animals ${ }^{1}$

\begin{tabular}{|c|c|c|c|c|c|c|c|}
\hline \multirow{2}{*}{$\overline{S r}$} & \multirow{2}{*}{$\begin{array}{c}\text { Age } \\
0-1\end{array}$} & \multicolumn{2}{|c|}{ Liver } & \multicolumn{2}{|c|}{ Cortex of the kidney } & \multicolumn{2}{|c|}{ Renal medulla } \\
\hline & & 77.2 & $(26.3-121)$ & 179 & $(59.3-251)$ & 228 & $(87.6-328)$ \\
\hline & $2-4$ & 66.4 & $(40.1-92.8)$ & 153 & $(84.3-222)$ & 164 & $(110-218)$ \\
\hline & $5-8$ & 73.5 & $(39.3-80.7)$ & 168 & (114-318) & 409 & (303-1017) \\
\hline & $9-13$ & 45.5 & $(23.5-135)$ & 136 & $(62.8-326)$ & 257 & $(40.7-609)$ \\
\hline & $16-28$ & 100 & $(48.0-283)$ & 199 & $(167-466)$ & 257 & $(168-439)$ \\
\hline \multirow[t]{5}{*}{$\mathrm{Ba}$} & $0-1$ & 229 & $(214-256)$ & 388 & $(240-570)$ & 366 & $(221-485)$ \\
\hline & $2-4$ & 243 & $(214-271)$ & 375 & $(261-489)$ & 374 & $(287-460)$ \\
\hline & $5-8$ & 230 & $(107-236)$ & 297 & $(265-367)$ & 355 & $(248-982)$ \\
\hline & $9-13$ & 242 & $(117-280)$ & 331 & $(154-461)$ & 328 & $(179-564)$ \\
\hline & $16-28$ & 228 & $(154-427)$ & 380 & $(252-508)$ & 346 & $(302-443)$ \\
\hline \multirow[t]{5}{*}{ Cd } & $0-1$ & 263 & $(67.6-611)^{a}$ & 3065 & $(315-8713)^{\mathrm{a}}$ & 294 & $(77.5-6800)^{a c}$ \\
\hline & $2-4$ & 475 & $(460-490)^{a}$ & 8167 & $(7412-8922)^{\mathrm{ab}}$ & 1776 & $(1429-2123)^{\mathrm{ad}}$ \\
\hline & $5-8$ & 743 & $(551-1577)^{\mathrm{ab}}$ & 6606 & $(5729-8781)^{\mathrm{ab}}$ & 1141 & $(738-2646)^{\mathrm{ad}}$ \\
\hline & $9-13$ & 976 & $(699-3669)^{b}$ & 14312 & $(7633-42819)^{\mathrm{ab}}$ & 6031 & $(3422-17500)^{b c}$ \\
\hline & $16-28$ & 1536 & $(798-3700)^{b}$ & 24027 & $(3048-36562)^{b}$ & 9273 & $(489-35091)^{b d}$ \\
\hline \multirow[t]{5}{*}{$\mathrm{Cu}$} & $0-1$ & 6057 & $(5609-14609)^{a}$ & 5995 & $(4347-10732)$ & 1960 & $(1821-5331)^{\mathrm{ab}}$ \\
\hline & $2-4$ & 3473 & $(2871-4074)^{\mathrm{ab}}$ & 3947 & (3709-4185) & 1469 & $(1131-1807)^{a b}$ \\
\hline & $5-8$ & 3172 & $(2151-4613)^{b}$ & 3689 & (2488-6250) & 1295 & $(1100-1842)^{a}$ \\
\hline & $9-13$ & 3872 & $(2926-7966)^{\mathrm{ab}}$ & 5960 & (3009-11393) & 2182 & $(1542-6511)^{b}$ \\
\hline & $16-28$ & 4281 & $(2403-5445)^{b}$ & 3996 & (3194-5311) & 2108 & $(1360-3421)^{\mathrm{ab}}$ \\
\hline \multirow[t]{5}{*}{$\mathrm{Zn}$} & $0-1$ & 30609 & $(16724-96681)$ & 33881 & $(18866-47110)$ & 10902 & $(9230-17235)^{\mathrm{ab}}$ \\
\hline & $2-4$ & 18218 & (17781-18654) & 18020 & (16408-19633) & 10304 & $(9054-11554)^{\mathrm{ab}}$ \\
\hline & $5-8$ & 14857 & (14790-22329) & 20553 & $(15948-22537)$ & 10406 & $(8573-12449)^{a}$ \\
\hline & $9-13$ & 26164 & (8849-45690) & 25820 & $(13645-44963)$ & 16808 & $(11056-24653)^{b}$ \\
\hline & $16-28$ & 21675 & (12579-38140) & 21571 & (12323-29907) & 14390 & $(8935-21854)^{\mathrm{ab}}$ \\
\hline \multirow[t]{5}{*}{ Mn } & $0-1$ & 2727 & $(2252-3258)^{a}$ & 1281 & (609-1479) & 501 & $(288-1292)$ \\
\hline & $2-4$ & 1780 & $(1113-2447)^{\mathrm{ab}}$ & 926 & (564-1289) & 433 & $(248-618)$ \\
\hline & $5-8$ & 1186 & $(976-1877)^{b}$ & 711 & (542-1035) & 350 & $(290-363)$ \\
\hline & $9-13$ & 824 & $(515-1560)^{b}$ & 889 & (522-1246) & 521 & (318-1108) \\
\hline & $16-28$ & 1580 & $(544-2588)^{\mathrm{ab}}$ & 847 & (344-1268) & 403 & (242-744) \\
\hline \multirow[t]{5}{*}{$\mathrm{Cr}$} & $0-1$ & 137 & $(116-427)^{a}$ & 127 & $(16.3-188)$ & 97.5 & (91.2-188) \\
\hline & $2-4$ & 87.3 & $(52.3-122)^{\mathrm{ab}}$ & 61.1 & $(40.7-81.5)$ & 100 & $(84.4-116)$ \\
\hline & $5-8$ & 42.3 & $(40.5-145)^{\mathrm{ab}}$ & 36.5 & $(28.1-107)$ & 40.1 & $(27.6-103)$ \\
\hline & $9-13$ & 67.1 & $(22.0-118)^{b}$ & 64.7 & $(17.0-122)$ & 121 & $(38.7-348)$ \\
\hline & $16-28$ & 140 & $(34.2-178)^{\mathrm{ab}}$ & 96.9 & $(19.4-514)$ & 86.3 & $(27.9-119)$ \\
\hline \multirow[t]{5}{*}{ Sb } & $0-1$ & 15.3 & $(0.00-21.6)$ & 11.7 & $(0.00-12.4)$ & 11.0 & $(0.00-11.5)$ \\
\hline & $2-4$ & 10.5 & $(0.00-20.9)$ & 6.05 & $(0.00-12.1)$ & 5.67 & $(0.00-11.3)$ \\
\hline & $5-8$ & 0.00 & $(0.00-14.8)$ & 0.00 & $(0.00-12.0)$ & 0.00 & $(0.00-11.6)$ \\
\hline & $9-13$ & 0.00 & $(0.00-18.5)$ & 0.00 & $(0.00-12.5)$ & 0.00 & $(0.00-11.6)$ \\
\hline & $16-28$ & 17.1 & $(0.00-23.8)$ & 11.1 & $(0.00-13.5)$ & 10.9 & $(0.00-12.0)$ \\
\hline \multirow[t]{2}{*}{ Se } & $0-1$ & 130 & $(109-201)^{\mathrm{ab}}$ & 771 & (539-1088) & 213 & $(150-647)^{\mathrm{a}}$ \\
\hline & $2-4$ & 180 & $(120-240)^{\mathrm{ab}}$ & 896 & $(721-1070)$ & 253 & $(234-273)^{\mathrm{ab}}$ \\
\hline
\end{tabular}


Table 5 Concentrations ( $\mu \mathrm{g} / \mathrm{kg}$ ) of strontium (Sr), barium (Ba), cadmium (Cd), copper (Cu), zinc (Zn), manganese (Mn), chromium $(\mathrm{Cr})$, antimony $(\mathrm{Sb})$, selenium $(\mathrm{Se})$ and lead $(\mathrm{Pb})$ in the liver and kidneys of horses, depending on the age of the animals ${ }^{1}$ (Continued)

\begin{tabular}{cccccccc}
\hline & $\mathbf{5 - 8}$ & 72.6 & $(71.0-180)^{\mathrm{a}}$ & 544 & $(468-1599)$ & 95.2 & $(87.5-124)^{\mathrm{b}}$ \\
& $\mathbf{9 - 1 3}$ & 130 & $(69.6-319)^{\mathrm{ab}}$ & 516 & $(356-1197)$ & 246 & $(147-542)^{\mathrm{a}}$ \\
$\mathbf{P b} \quad$ & $\mathbf{1 6 - 2 8}$ & $(99.3-336)^{\mathrm{b}}$ & 834 & $(400-981)$ & 325 & $(171-522)^{\mathrm{a}}$ \\
& $\mathbf{0 - 1}$ & 70.6 & $(62.5-136)$ & 37.2 & $(0.00-114)$ & 23.9 & $(0.00-33.5)$ \\
& $\mathbf{2 - 4}$ & 91.8 & $(25.9-158)$ & 32.3 & $(8.17-56.5)$ & 17.4 & $(6.51-28.2)$ \\
& $\mathbf{5 - 8}$ & 82.3 & $(0.00-90.7)$ & 25.9 & $(0.00-84.7)$ & 16.1 & $(0.00-21.0)$ \\
& $\mathbf{9 - 1 3}$ & 110 & $(45.1-170)$ & 21.1 & $(6.76-77.2)$ & $(2.48-40.5)$ \\
& $\mathbf{1 6 - 2 8}$ & 106 & $(0.00-301)$ & 35.2 & $(0.00-118)$ & 22.1 & $(0.00-103)$ \\
\hline
\end{tabular}

${ }^{1} \mathrm{n}=4$ (0-1 years), $\mathrm{n}=2$ ( $2-4$ years), $\mathrm{n}=3$ (5-8 years), $\mathrm{n}=6$ (9-13 years), $\mathrm{n}=6$ ( $16-28$ years)

Group comparisons were separately calculated for each element and each tissue. Differences $(P<0.05)$ within a column are marked with different superscript letters.

exist in Germany (Gudehus 2006), the origin of slaughtered horses largely differ. In particular, age and field of use (e.g. sports or leisure riding, reproduction) of the horses vary (Gudehus 2006). The horses chosen for the present investigation might therefore represent the situation regarding the origin of meat producing horses in Germany. However, the observed individual variations in the element concentrations in the equine liver and kidneys indicate differences in the exposure of the horses to environmental contaminants and dietary mineral supply. With regard to the use of equine by-products in the food chain, variations in the uptake of specific environmental contaminants and trace elements by the ingestion of equine organs can be assumed and should be considered for risk assessment in human and animal nutrition.

As a first interesting result, $\mathrm{Cu}$ was stored in approximately identical amounts in the liver (4238 (2151-14609) $\mu \mathrm{g} / \mathrm{kg})$ and renal cortex (4448 (2488-11393) $\mu \mathrm{g} / \mathrm{kg})$ of the

Table 6 Dependence of the storage of strontium (Sr), barium (Ba), cadmium (Cd), copper (Cu), zinc $(\mathrm{Zn})$, manganese ( $\mathrm{Mn})$, chromium ( $\mathrm{Cr}$ ), antimony ( $\mathrm{Sb})$, selenium $(\mathrm{Se})$ and lead $(\mathrm{Pb})$ in the liver and kidneys of horses $(n=21)$ on the sex and age of the animals ( $P$-values)

\begin{tabular}{ccccccc}
\hline & \multicolumn{2}{c}{ Liver } & \multicolumn{2}{c}{ Cortex of the kidney } & \multicolumn{2}{c}{ Renal medulla } \\
\hline & Sex & Age & Sex & Age & Sex & Age \\
$\mathrm{Sr}$ & 0.350 & 0.128 & 0.890 & 0.289 & 0.211 & 0.701 \\
$\mathrm{Ba}$ & 0.388 & 0.331 & 0.129 & 0.420 & 0.809 & 0.721 \\
$\mathrm{Cd}$ & 0.997 & 0.158 & 0.652 & $\mathbf{0 . 0 3 9}$ & 0.982 & 0.214 \\
$\mathrm{Cu}$ & 0.569 & 0.413 & 0.575 & 0.156 & 0.786 & 0.593 \\
$\mathbf{Z n}$ & 0.908 & 0.259 & 0.940 & 0.276 & 0.318 & 0.138 \\
$\mathrm{Mn}$ & 0.151 & 0.843 & $\mathbf{0 . 0 2 6}$ & 0.465 & 0.135 & 0.692 \\
$\mathbf{C r}$ & 0.363 & 0.997 & 0.567 & 0.395 & $\mathbf{0 . 0 1 5}$ & 0.121 \\
$\mathbf{S b}$ & 0.379 & 0.550 & 0.356 & 0.562 & 0.393 & 0.596 \\
$\mathrm{Se}$ & 0.145 & $\mathbf{0 . 0 1 2}$ & 0.345 & 0.557 & 0.077 & 0.128 \\
$\mathrm{~Pb}$ & 0.745 & 0.961 & 0.704 & 0.996 & 0.688 & 0.438 \\
\hline
\end{tabular}

horses. The liver is considered to be a storage organ for $\mathrm{Cu}$ (Plumlee and Johnson 1996), and comparable amounts of $\mathrm{Cu}$ were also measured in the equine liver in a previous study (Hecht 1984). However, the $\mathrm{Cu}$ concentrations in the renal cortex and renal medulla (1853 (1100-6511) $\mu \mathrm{g} /$ $\mathrm{kg}$ ) observed in the present study were lower than previously measured in the renal cortex of female $(7300 \mu \mathrm{g} / \mathrm{kg})$ and male $(7500 \mu \mathrm{g} / \mathrm{kg}$ ) horses (Koizumi et al. 1989). No gender-related differences were observed for the storage of $\mathrm{Cu}$ in the present study, and only small age-dependent variations were detected, with the highest hepatic $\mathrm{Cu}$ concentrations in foals up to 1 year and lower $(P<0.05)$ concentrations in middle-aged (5-8 years) and old (16-28 years) horses. In the renal medulla, lowest $\mathrm{Cu}$ concentrations were measured in horses between 5-8 years and highest in horses between 9-13 years. These findings are only partly in accordance with further data from horses (Plumlee and Johnson 1996), where no gender- or agerelated differences were detected for the $\mathrm{Cu}$ concentrations in the equine liver and kidneys. In general, the storage of $\mathrm{Cu}$ in the organism depends on the amount, kind and duration of $\mathrm{Cu}$ supplementation, and the concentration of protein, $\mathrm{Zn}$ and iron in the diet. Moreover, the status of the animal and the used feed additives are important factors (Prothmann 1975). In this context, recent data from cattle (Miranda et al. 2006a; Waegeneers et al. 2009) indicate dietary differences between horses and cattle, but also differences in the storage of $\mathrm{Cu}$ in the organism. In these studies (Miranda et al. 2006a; Waegeneers et al. 2009), marked higher hepatic $\mathrm{Cu}$ concentrations were found in cattle $(34.3(1.86-181) \mathrm{mg} / \mathrm{kg}$ and $80.1 \pm 66.7 \mathrm{mg} / \mathrm{kg}$, respectively), while the renal $\mathrm{Cu}$ concentrations were comparable to the presently measured $\mathrm{Cu}$ concentrations in the renal cortex of the horses. Unfortunately, the present study design did not allow an estimation of the feeding regime of the horses. Further studies are required to explain the detected inter- and intra-species related differences. 
Similar to the results on the $\mathrm{Cu}$ concentrations, $\mathrm{Zn}$ was also equally stored in the liver and the renal cortex of the horses. No differences were observed depending on the sex of the animals, which is in accordance with further studies (Hecht 1986; Koizumi et al. 1989). While Hecht (1986) could not find an age-dependency for the storage of $\mathrm{Zn}$ in the equine liver and kidney, the present study could also demonstrate only one group difference for the $\mathrm{Zn}$ concentrations in the renal medulla of the horses, with lower amounts in horses between 5-8 years compared to horses between 9-13 years. In general, the measured hepatic Zn concentrations (21387 (8849-96681) $\mu \mathrm{g} / \mathrm{kg}$ ) were approximately $50 \%$ lower compared to data from previous studies in horses (Kowalczyk et al. 1986; Koizumi et al. 1989) and cattle (Miranda et al. 2006a; Waegeneers et al. 2009). The detected $\mathrm{Zn}$ concentrations in the cortex (21956 (12323-47110) $\mu \mathrm{g} / \mathrm{kg})$ and medulla (12895 $(8573-24653) \mu \mathrm{g} / \mathrm{kg}$ ) of the kidneys were in accord with previous results in horses (Koizumi et al. 1989) and cattle (Miranda et al. 2006a; Waegeneers et al. 2009), while another study found markedly higher $\mathrm{Zn}$ concentrations in the equine liver (88100-109000 $\mu \mathrm{g} / \mathrm{kg}$ ) and kidneys (37700-52900 $\mu \mathrm{g} / \mathrm{kg}$ ) (Hecht 1984). For the interpretation of the present results, it should be taken into consideration that the $\mathrm{Zn}$ accumulation in the equine organism might partly depend on the environmental pollution. Farmer and Farmer (2000) evaluated the $\mathrm{Zn}$ concentrations in the liver and kidneys of horses in a metal processing region in eastern Kazakhstan and found markedly higher $\mathrm{Zn}$ values in the equine liver $(37.73 \pm 3.95 \mathrm{mg} /$ $\mathrm{kg}$ in the district Tavricheskiy and $63.28 \pm 4.33 \mathrm{mg} / \mathrm{kg}$ in the district Samarskiy) and in the equine kidneys (36.05 \pm $4.43 \mathrm{mg} / \mathrm{kg}$ in the district Tavricheskiy and $49.39 \pm 4.03$ $\mathrm{mg} / \mathrm{kg}$ in the district Samarskiy) than in the present study or in the previous studies of Kowalczyk et al. (1986) and Koizumi et al. (1989).

The Mn concentrations were the highest in the liver of the horses, followed by the renal cortex and the renal medulla. In general, female horses stored less $\mathrm{Mn}$ in the organs compared to male horses, however, this difference was only statistically significant in the renal cortex. Considering the age of the animals, the hepatic Mn concentrations were higher in foals $(0-1$ year) compared to middle-aged horses (5-13 years). No age-effect was observed for the Mn concentrations in the cortex and medulla of the kidneys. Partially, these findings contrast with observations in humans, where a gender- and agedependency was found for the storage of $\mathrm{Mn}$ in the organism (Anke et al. 1978). The authors reported that women showed higher $\mathrm{Mn}$ concentrations in the rips and kidneys compared to men and that the Mn concentrations decreased with age. However, another study could not demonstrate an age-dependency for the Mn accumulation in humans (Schroeder et al. 1966). The higher Mn concentrations in foals compared to older horses, as observed in the present study, are in accordance with findings in cats, where the highest Mn concentrations in the liver and bones were found in kittens at an age of 4 weeks resp. 8-12 weeks compared to adult cats (Stratmann 1988).

Highest Se concentrations were found in the renal cortex (739 (356-1599) $\mu \mathrm{g} / \mathrm{kg}$ ), while markedly lower concentrations were detected in the renal medulla (255 (87.5$647) \mu \mathrm{g} / \mathrm{kg})$ and the liver $(131(69.6-336) \mu \mathrm{g} / \mathrm{kg})$ of the horses. The measured Se concentrations are comparable to data reported in cattle (Salisbury et al. 1991). The Se concentrations were lower in horses between 5-8 years when compared to horses between 16-28 years (liver) or when compared to horses between $0-1$ and 9-28 years (renal medulla). These findings are in contrast to data of Teilmann and Hansen (1984), where no age-dependency was observed for the Se concentrations in the kidneys of horses. In general, the main natural source of Se for horses are plants, while the amounts of Se differ depending on the Se concentrations in the soil (Zhu et al. 2009). An excess of Se, either in seleniferous regions or by an oversupplementation, can result in toxicosis (Coenen 2013). Desta et al. (2011) reported that horses showed toxic Se concentrations in the liver $(6.13 \pm 0.31 \mathrm{mg} / \mathrm{kg})$ and in the kidneys $(6.25 \pm 0.3 \mathrm{mg} / \mathrm{kg})$, probably resulting from an injection of a toxic Se preparation.

Cd was mainly stored in the kidneys of the horses, with the highest concentrations in the renal cortex $(8713$ (315-42819) $\mu \mathrm{g} / \mathrm{kg}$ ), followed by the renal medulla (4647 $(77.5-35091) \mu \mathrm{g} / \mathrm{kg})$ and the liver $(798(67.6-3700) \mu \mathrm{g} / \mathrm{kg})$. The amounts were always higher in female horses compared to male horses, however, this difference was only statistically significant for the hepatic Cd concentrations. The higher Cd accumulation in female horses is in accord with previous studies in horses (Baldini et al. 2000) and humans (Kjellström 1979). The analysis of age-related differences demonstrated that young horses showed lower amounts of $\mathrm{Cd}$ in the liver and kidneys compared to older horses. This finding is in accordance with further data from horses (Baldini et al. 2000) and cattle (Rudy 2009), however, other authors found an increase of Cd with increasing age of horses (Salmi and Hirn 1981) and humans (Anke et al. 1978), but a subsequent decrease at an older age. In general, the presently measured hepatic $\mathrm{Cd}$ concentrations were lower than further results in horses (Salmi and Hirn 1981; Baldini et al. 2000; Farmer and Farmer 2000), and also lower Cd concentrations were found in the kidneys of the horses when compared to previous data (Elinder et al. 1981; Salmi and Hirn 1981; Junnila et al. 1987; Baldini et al. 2000; Farmer and Farmer 2000; Beldomenico et al. 2001). Interestingly, the measured $\mathrm{Cd}$ concentrations in the livers and kidneys of the horses were markedly 
higher compared to cattle (Rudy 2009; Waegeneers et al. 2009).

An explanation for the lower $\mathrm{Cd}$ concentrations in the equine liver and kidneys demonstrated in the present study compared to the results of previous studies in horses could possibly be found in the environmental load, since it was assumed that horses can be considered as an indicator for the Cd pollution (Elinder 1981; Farmer and Farmer 2000). The higher Cd concentrations in the organs of horses compared to cattle might be explained by the higher age at the time of slaughtering.

$\mathrm{Cd}$ concentrations in the food chain are of current interest for risk assessment. The EFSA Scientific Panel on Contaminants in the Food Chain (2004a) has indicated that the ingestion of liver and kidneys of horses, ruminants and wildlife can considerably contribute to human overall Cd exposure. According to Regulation (EC) No 1881/2006 latest amended by Regulation (EC) No 629/2008, the maximum level for $\mathrm{Cd}$ in liver of horses is $0.50 \mathrm{mg} / \mathrm{kg}$ fresh weight, and the maximum level for $\mathrm{Cd}$ in kidneys of horses $1.0 \mathrm{mg} / \mathrm{kg}$ fresh weight. Both maximum levels have been exceeded in the present study when the median values were considered. The EFSA Panel on Contaminants in the Food Chain (2009) indicates that 3.7\% of liver samples (bovine, sheep, pig, poultry, horse) and $0.96 \%$ of kidney samples (bovine, sheep, pig, poultry, horse) have exceeded the maximum levels for $\mathrm{Cd}$. The present data underline the relevance of equine organs in the food chain for human $\mathrm{Cd}$ exposure and confirm the opinion of the EFSA Panel on Contaminants in the Food Chain (2009; 2011) that the Cd exposure of humans should be reduced.

The $\mathrm{Sr}$ concentrations were the highest in the renal medulla, followed by the renal cortex and the liver. No gender- or age-dependent differences were detected. This is in contrast to findings in humans, where newborns and children up to 9 years showed higher $\mathrm{Sr}$ concentrations in the kidneys and liver compared to adults, and persons older than 50 years accumulated increased amounts of $\mathrm{Sr}$ in the kidneys (Schroeder et al. 1972). Possible explanations for these variations may include differences in the living conditions or basic food resource, which needs further evaluation in future studies.

The Ba concentrations in the liver of the horses (230 $(107-427) \mu \mathrm{g} / \mathrm{kg}$ ) were lower when compared to the renal cortex $(340(154-570) \mu \mathrm{g} / \mathrm{kg})$ and the renal medulla (355 (179-982) $\mu \mathrm{g} / \mathrm{kg})$. No age- or gender-related differences could be detected for the hepatic and renal $\mathrm{Ba}$ concentrations. This is in contrast to findings in humans, where the Ba concentrations in the liver and kidneys of children were higher compared to the amounts in the organs of older persons (Schroeder et al. 1972). The authors also indicated that the geographic background of humans is important for the storage of $\mathrm{Ba}$ in the organism.
$\mathrm{Pb}$ was mainly accumulated in the liver (82.3 (0.00301) $\mu \mathrm{g} / \mathrm{kg}$ ) of the horses when compared to the cortex $(34.0(0.00-118) \mu \mathrm{g} / \mathrm{kg})$ and medulla $(18.2(0.00-103) \mu \mathrm{g} / \mathrm{kg})$ of the kidneys, while no age- or gender-related differences were observed. This observation is in contrast to data of cattle, where increased hepatic $\mathrm{Pb}$ concentrations were detected with age (Rudy 2009). In this study (Rudy 2009), the $\mathrm{Pb}$ concentrations in the liver of cattle $(0.125-0.179 \mathrm{mg} / \mathrm{kg})$ were higher than presently measured in the equine organs, while other authors (Waegeneers et al. 2009) found comparable amounts in the bovine liver $(0.082 \pm 0.126 \mathrm{mg} / \mathrm{kg})$, but higher $\mathrm{Pb}$ concentrations in the bovine kidneys $(0.212 \pm 0.209 \mathrm{mg} / \mathrm{kg})$. In this context, it should not go unmentioned that Blanco-Penedo et al. (2006) found a positive correlation between the hepatic $\mathrm{Cu}$ and $\mathrm{Pb}$ accumulation in cattle, why the authors suggest an interaction of these elements after ingestion. Further studies should evaluate the metabolism of these two elements and the potential impact on hepatic storage, not only in the bovine, but also in the equine organism.

As $\mathrm{Pb}$ is an important environmental contaminant, its concentrations in the equine organs may depend on the exposure of the animals. Horses in a metal processing region in eastern Kazakhstan (Farmer and Farmer 2000) showed markedly higher $\mathrm{Pb}$ concentrations in the liver $(1.29-2.22 \mathrm{mg} / \mathrm{kg})$ and kidneys $(0.84-1.27 \mathrm{mg} / \mathrm{kg})$ compared to the horses of the present study. The hepatic $(0.75-1.02 \mathrm{mg} / \mathrm{kg})$ and renal $(0.72-1.03 \mathrm{mg} / \mathrm{kg}) \mathrm{Pb}$ concentrations were also higher in cattle of this metal processing region. When compared to previous data from horses in Central Europe (Kośla et al. 1989), the presently measured $\mathrm{Pb}$ concentrations in the equine organs were lower than 25 years ago $(1.8 \pm 1.7 \mathrm{mg} / \mathrm{kg}$ dry matter of the liver and $1.2 \pm 0.72 \mathrm{mg} / \mathrm{kg}$ dry matter of the kidney). This observation may indicate a reduced environmental $\mathrm{Pb}$ pollution and therefore a reduced health risk for horses, but also for humans in Central Europe. The EFSA Scientific Panel on Contaminants in the Food Chain (2004b) concluded that food of animal origin is not the main source for human $\mathrm{Pb}$ exposure. However, variations may depend on environmental pollution. In this context, reports on lead poisoning exist for horses and other livestock in contaminated areas (e.g. Levine et al. 1976; Palacios et al. 2002; Lemos et al. 2004; Miranda et al. 2006b; Rodríguez-Estival et al. 2012). In 2010, the EFSA Panel on Contaminants in the Food Chain (CONTAM) (2010) has indicated that human exposure to $\mathrm{Pb}$ should be reduced and recommended to enhance the EFSA food category database. Overall, the present data may not only demonstrate a reduction of $\mathrm{Pb}$ concentrations in the organs of horses when compared to data 25 years ago, but may also expand the data pool on $\mathrm{Pb}$ concentrations in equine by-products.

The hepatic $\mathrm{Cr}$ concentrations did not differ when compared to the amounts in the renal cortex and medulla. 
Foals up to 1 year showed higher (137 (116-427) $\mu \mathrm{g} / \mathrm{kg}$ ) hepatic $\mathrm{Cr}$ concentrations than horses between 9-13 years $(67.1(22.0-118) \mu \mathrm{g} / \mathrm{kg})$, and lower $\mathrm{Cr}$ concentrations were detected in the renal medulla of female horses when compared to male horses. The Sb concentrations in the liver of the horses were higher than in the renal cortex and medulla, while no gender- or age-dependencies were detected for the storage. In general, comparable Sb concentrations were measured in the liver and kidneys of humans (Sumino et al. 1975). Since little is known about the storage of $\mathrm{Cr}$ and $\mathrm{Sb}$ in the organism, further studies are needed to evaluate the metabolism of these elements and to explain the age- and gender-related differences for the storage of $\mathrm{Cr}$ in horses. However, the present data add valuable information on the $\mathrm{Cr}$ concentrations in organs of horses, which can be used for animal, but also for human nutrition. In particular, the EFSA Panel on Contaminants in the Food Chain (CONTAM) (2014) recently recommended to generate data on the $\mathrm{Cr}$ concentrations in food, why the present results may be relevant not only for diagnostics, but also for risk assessment.

\section{Conclusion}

When compared to other animals, the measured amounts of $\mathrm{Sr}, \mathrm{Ba}, \mathrm{Cd}, \mathrm{Cu}, \mathrm{Zn}, \mathrm{Mn}, \mathrm{Cr}, \mathrm{Sb}, \mathrm{Se}$ and $\mathrm{Pb}$ in the livers and kidneys of horses often differed, possibly because of varying living or feeding conditions. The present data are of practical relevance, since horses could partially be considered as an indicator for the environmental pollution, and the equine liver and kidneys are edible animal byproducts in the food chain. Interestingly, the measured concentrations of $\mathrm{Sr}, \mathrm{Ba}, \mathrm{Cd}, \mathrm{Cu}, \mathrm{Zn}, \mathrm{Mn}, \mathrm{Cr}, \mathrm{Sb}, \mathrm{Se}$ and $\mathrm{Pb}$ showed only small variations depending on the age or sex of the animals, which is in contrast to observations in other species. Future studies should evaluate the metabolism of the elements in the equine organism to explain the detected species-specific differences.

\section{Additional file}

Additional file 1: Table S1. Sex, age, breed and pathomorphological findings of the horses included in this study.

\section{Competing interests}

The authors declare that they have no competing interests.

\section{Authors' contribution}

NP wrote the manuscript and carried out data analysis. BM carried out sample analysis and participated in data analysis and literature review. ML-W and HS participated in study design and review of the manuscript. RP participated in sample analysis. AB provided information on the pathomorphological findings of the horses and participated in reviewing the manuscript. KN participated in data analysis. JZ participated in study design, data analysis and review of the manuscript. All authors read and approved the final manuscript.

\section{Author details}

${ }^{1}$ Institute of Animal Nutrition, Department of Veterinary Medicine, Freie Universität Berlin, Königin-Luise-Str. 49, Berlin 14195, Germany. ${ }^{2}$ Federal Institute for Risk Assessment, Max-Dohrn-Str. 8-10, Berlin 10589, Germany. ${ }^{3}$ Institute of Veterinary Pathology, Department of Veterinary Medicine, Freie Universität Berlin, Robert-von-Ostertag-Str. 15, Berlin 14163, Germany.

${ }^{4}$ Institute of Biometry and Clinical Epidemiology, Charité -

Universitätsmedizin Berlin, Hindenburgdamm 30, Berlin 12203, Germany.

Received: 9 February 2014 Accepted: 3 June 2014

Published: 8 July 2014

\section{References}

Anke M, Schneider HJ, Grün M, Groppel B, Hennig A (1978) Die Diagnose des Mangan-, Zink- und Kupfermangels und der Kadmiumbelastung. Zbl Pharm Pharmakother Labdiagn 117:688-707

Baldini M, Stacchini P, Cubadda F, Miniero R, Parodi P, Facelli P (2000) Cadmium in organs and tissues of horses slaughtered in Italy. Food Add Cont 17:679-687

Beldomenico HR, Baroni E, Campagnoli DU, Sigrist ME, Rubio M, Boggio JC (2001) Cadmium accumulation and distribution in slaughtered horse kidneys from the Argentine central region. Arch Envion Contam Toxicol 41:100-103

Blanco-Penedo I, Cruz JM, López-Alonso M, Miranda M, Castillo C, Hernández J, Benedito $J L$ (2006) Influence of copper status on the accumulation of toxic and essential metals in cattle. Environ Int 32:901-906

Brown MJ, Margolis S (2012) Lead in drinking water and human blood lead levels in the United States. MMWR Surveill Summ 61(Suppl):1-9

Ciobanu C, Slencu BG, Cuciureanu R (2012) Estimation of dietary intake of cadmium and lead through food consumption. Rev Med Chir Soc Med Nat lasi 116:617-623

Coenen M (2013) Macro and trace elements in equine nutrition. In: Geor RJ, Harris PA, Coenen M (eds) Equine Applied and Clinical Nutrition. Elsevier Ltd.

Daunderer M (1998) Antimon. In: Handbuch der Umweltgifte. Toxikologische Einzelstoffinformationen, Abschnitt III-3. Ecomed, Landsberg/Lech

Desta B, Maldonado G, Reid H, Puschner B, Maxwell J, Agasan A, Humphreys L, Holt T (2011) Acute selenium toxicosis in polo ponies. J Vet Diagn Invest 23:623-628

EFSA Panel on Contaminants in the Food Chain (2009) Scientific opinion. Cadmium in food. EFSA J 980:1-139

EFSA Panel on Contaminants in the Food Chain (CONTAM) (2010) Scientific opinion on lead in food. EFSA J 8:1570

EFSA Panel on Contaminants in the Food Chain (CONTAM) (2011) Scientific opinion. Statement on tolerable weekly intake for cadmium. EFSA J 9:1975

EFSA Panel on Contaminants in the Food Chain (CONTAM) (2014) Scientific opinion on the risks to public health related to the presence of chromium in food and drinking water. EFSA J 12:3595

EFSA Scientific Panel on Contaminants in the Food Chain (2004a) Opinion of the Scientific Panel on Contaminants in the Food Chain on a request from the Commission related to cadmium as undesirable substance in animal feed. EFSA J 72:1-24

EFSA Scientific Panel on Contaminants in the Food Chain (2004b) Opinion of the Scientific Panel on Contaminants in the Food Chain on a request from the Commission related to lead as undesirable substance in animal feed. EFSA J 71:1-20

Elinder CG (1981) Early Effects of Cadmium Accumulation in Horse Kidney Cortex. Proceedings of the International Conferences. Heavy metals in environment, Amsterdam. CEP Consultants, Edinburgh, In

Elinder CG, Jönsson L, Piscator M, Rahnster B (1981) Histopathological changes in relation to cadmium concentration in horse kidneys. Environ Res 26:1-21

Farmer AA, Farmer AM (2000) Concentrations of cadmium, lead and zinc in livestock feed and organs around a metal production centre in eastern Kazakhstan. Sci Total Environ 257:53-60

Gudehus AU (2006) Die Entwicklung der Pferdeschlachtung und des Pferdefleischkonsums in Deutschland unter Berücksichtigung der gesetzlichen Änderungen. University of Munich, Dissertation

Hecht H (1984) "Carry-over-Vorgänge" bei der Erzeugung vom Tier stammender Lebensmittel. Fleischwirtschaft 64:1204-1212

Hecht H (1986) Unterschiede der Gehalte an Spurenelementen in Muskeln und Organen von Wild- und landwirtschaftlichen Nutztieren. Fleischwirtschaft 66:1246-1252 
Junnila M, Korkeala H, Rahko T, Salmi S (1987) The interactions of cadmium and selenium in horse kidney cortex in relation to histopathological changes. Acta Vet Scand 28:201-208

Kjellström T (1979) Exposure and accumulation of cadmium in populations from Japan, the U.S. and Sweden. Environ Health Perspect 28:169-197

Koizumi N, Inoue Y, Ninomiya R, Fujita D, Tsukamoto T (1989) Relationship of cadmium accumulation to zinc or copper concentration in horse liver and kidney. Environ Res 49:104-114

Kośla T, Anke M, Grün M (1989) The lead status of horses from central Europe depending on breed, sex, age and living area. Arch Tierernahr 39:667-674

Kowalczyk DF, Gunson DE, Shoop CR (1986) The effects of natural exposure to high levels of zinc and cadmium in the immature pony as a function of age Environ Res 40:285-300

Lemos RA, Driemeier D, Guimarães EB, Dutra IS, Mori AE, Barros CS (2004) Lead poisoning in cattle grazing pasture contaminated by industrial waste. Vet Hum Toxicol 46:326-328

Levine RJ, Moore RM, McLaren GD, Barthel WF, Landrigan PJ (1976) Occupational lead poisoning, animal deaths, and environmental contamination at a scrap smelter. Am J Public Health 66:548-552

Miranda M, Alonso ML, Benedito JL (2006a) Copper, zinc, iron, and manganese accumulation in cattle from Asturias (northern Spain). Biol Trace Elem Res 109:135-143

Miranda M, López-Alonso M, García-Partida P, Velasco J, Benedito JL (2006b) Long-term follow-up of blood lead levels and haematological and biochemical parameters in heifers that survived an accidental lead poisoning episode. J Vet Med A Physiol Pathol Clin Med 53:305-310

Palacios H, Hibarren I, Olalla MJ, Cala V (2002) Lead poisoning of horses in the vicinity of a battery recycling plant. Sci Total Environ 290:81-89

Plumlee KH, Johnson B (1996) Heavy metal concentrations in injured racehorses. Vet Hum Toxicol 38:204-206

Prothmann I (1975) Zum Kupfer-, Eisen-, Zink- und Wassergehalt in Organen und Geweben beim Schwein nach Verfütterung verschiedener Kupferverbindungen. In: Dissertation. University of Veterinary Medicine Hannover, Hannover (Germany)

Rodríguez-Estival J, Barasona JA, Mateo R (2012) Blood Pb and $\delta$-ALAD inhibition in cattle and sheep from a Pb-polluted mining area. Environ Pollut 160:118-124

Rudy M (2009) Correlation of lead, cadmium and mercury levels in tissue and liver samples with age in cattle. Food Addit Contam Part A Chem Anal Control Expo Risk Assess 26:847-853

Salisbury CD, Chan W, Saschenbrecker PW (1991) Multielement concentrations in liver and kidney tissues from five species of Canadian slaughter animals. J Assoc Off Anal Chem 74:587-591

Salmi A, Hirn J (1981) Der Cadmiumgehalt des Muskels, der Leber und Nieren finnischer Pferde und Rentiere. Fleischwirtschaft 61:1199-1201

Schroeder HA, Balassa JJ, Tipton IH (1966) Essential trace metals in man: manganese. A study in homeostasis. J Chron Dis 19:545-571

Schroeder HA, Tripton $1 \mathrm{H}$, Nason AP (1972) Trace metals in man: strontium and barium. J Chron Dis 25:491-517

Stratmann B (1988) Untersuchungen zur Körperzusammensetzung von Katzen. In: Dissertation. University of Veterinary Medicine Hannover, Hannover (Germany)

Streit B (1994) Lexikon Ökotoxikologie. VCH-Verlag, Weinheim

Sumino K, Hayakawa K, Shibata T, Kitamura S (1975) Heavy metals in normal Japanese tissues. Amounts of 15 heavy metals in 30 subjects. Arch Environ Health 30:487-494

Teilmann AM, Hansen JC (1984) Cadmium and selenium levels in kidneys from Danish horses. Nord Vet Med 36:49-56

Waegeneers N, Pizzolon JC, Hoenig M, De Temmerman L (2009) Accumulation of trace elements in cattle from rural and industrial areas in Belgium. Food Addit Contam Part A Chem Anal Control Expo Risk Assess 26:326-332

Zhu YG, Pilon-Smits EA, Zhao FJ, Williams PN, Meharg AA (2009) Selenium in higher plants: understanding mechanisms for biofortification and phytoremediation. Trends Plant Sci 14:436-442

doi:10.1186/2193-1801-3-343

Cite this article as: Paßlack et al:: Concentrations of strontium, barium, cadmium, copper, zinc, manganese, chromium, antimony, selenium and lead in the equine liver and kidneys. SpringerPlus 2014 3:343.

\section{Submit your manuscript to a SpringerOpen ${ }^{\odot}$ journal and benefit from:}

- Convenient online submission

- Rigorous peer review

- Immediate publication on acceptance

- Open access: articles freely available online

- High visibility within the field

- Retaining the copyright to your article

Submit your next manuscript at $>$ springeropen.com 